\title{
A Brief History of Imperial Roman Canon Law
}

$\mathrm{O}$

N MAY 19, 1918, there went into effect the latest of all the modern Codes, - the new Code of Canon Law of the Catholic Church. ${ }^{1}$ This is certainly one of the greatest literary juridical achievements of the 20th century: it is most remarkable that the enormous ecclesiastical jurisprudence of the Roman Church has been condensed and gathered into one small octavo volume of only 448 pages. The new Codex Juris Canonici is a true code and like in form to any of the Modern Codes, such as the French Civil Code.

It was Pope Pius $\mathrm{X}$ who designed, and initiated in the year 1904 , the gigantic task of restating and codifying the vast ecclesiastical jurisprudence of a world-wide church, then scattered in the voluminous 12th-16th century Corpus Juris Canonici ${ }^{2}$ and

gained, free growth and development is promoted. In other words, the subject for uniform laws should be matters well established, like bills and notes, where the law is either one way or the other, and it is desirable that it should be uniform.

For experimental matters, such as land transfers, it is highly undesirable that any uniform act should be passed in advance of practical experience. Space does not permit an analysis of the proposed uniform act and its effect in California. But the present California Act was devised with consideration for the present unrepealed local law, although as has been seen it fits very poorly. The uniform act pays no attention to local conditions. Almost every objection made to the California Act may be made to the uniform act and innumerable additional ones, as might be expected from a ready-made statute on a subject affecting almost every department of substantive law and procedure, conveyances, mortgages, easements, trusts, liens, judgments, executions, attachments, administrations, etc., a statute drafted without any detailed study of the system into which it is supposed to fit.

Proponents of the Massachusetts judicial system for example, do not believe any other is practicable. Judge Davis in the report of the New York Bar Association for 1908, at p. 408 says, "I do not believe it would be practicable to have a system which, under our written law must of necessity be a judicial system operate not like the English and provincial acts, purely as a ministerial function, but solely through proceedings in court and by order of a judge after judicial process. I do not believe it would be practicable to have such an act administered, except under the immediate direction of a special court."

${ }_{1}$ Codex Juris Canonici Pii $X$ Pontificis Maximi jussu digestus, Benedicti Papae XV auctoritate promulgatus. Praefatione, fontium annotatione et indice analytico-alphabetico ab emo. Petro Card. Gasparri auctus, $\mathrm{New}$ York, Kenedy \& Sons, 1918. It was promulgated May 27, 1917 (Pentecost) to become operative on Pentecost the year following (May 19, 1918).

2 Described in detail in Sherman, Roman law in the modern world, vol. i, $\$ \S 226-230$. 
the vast number of ecclesiastical enactments since the 16th century. This novel and arduous work of codification lasted 13 years, the main burden being borne by that learned and distinguished Canonist, the present Papal Secretary of State, Cardinal Gasparri, to whom the present Pope, Benedict XV, gave an unusual tribute of praise a few months before he promulgated the new Codex Juris Canonici. ${ }^{3}$

This latest 20th century code, most admirable in its succintness, lucid brevity, and orderly intelligibility, is naturally reviving an interest in the jurisprudence of Christianity which had its origin in the period of the Roman Empire, especially from Constantine the Great onward. This is a subject which should perforce interest all modern peoples whether Catholic or Protestant, for the period to be considered is characterized by one undivided Christian Church which has given to modern Europe and America its dominent theology.

For it should never be forgotten that the Canon law was the medium through which the Christian Church aided the preservation of Roman Civil law to modern times. "The laws of Justinian have been woven into the fabric of the Canon law and in that form . . . . obtained the sanction of the Church." $*$ For instance, the Roman law of charities has entered the AngloAmerican common law via Canon law. It was the first Christian Emperor, Constantine the Great, who in the year $315 \mathrm{~A}$. D. empowered his subjects to bequeath their property to the Church. So freely and frequently was this permission subsequently acted upon, that half a century later Christian churches and religious orders were found to own a vast quantity of property. And with this accumulation came social abuses, so much so that in the year 364 the Emperor Valentinian enacted a mortmain law to prevent accumulation of property by churches and religious corporations. But this restraint soon passed away and a century and $a$ half later in the time of Justinian it became a settled principle of law that legacies for pious or charitable uses should receive special favor in the courts and be regarded as privileged. And wills containing charitable dispositions of property became more liberally construed than other wills: no such legacy or devise was suffered to be lost because the object destined by the testator became uncertain or failed. A legacy to God was

${ }^{3}$ In the secret consistory of December 4, 1916.

4 Morey, Roman law, p. 206. 
construed to go to the parish of the testator. And Roman courts might designate the persons entitled to receive the gift. As soon as the use of wills was permitted in England, these and other principles of the Roman law of charities were introduced into the English Common law by the English Chancellors; they, down to the 16th century and the time of Henry VIII, were always ecclesiastics of the Roman Catholic Church and of course educated in the medieval Roman Canon Law which was almost entirely of Roman Civil law origin as to things secular. $^{5}$

Origin of ecclesiastical jurisdiction in the Apostolic Era of the Church. Ecclesiastical jurisdiction means primarily authority exercised by ecclesiastical persons over other ecclesiastics and lay persons. It is not limited to ecclesiastics only. The beginnings of the exercise of spiritual authority over members of the church antedate the conversion of the Empire to Christianity, and go back. to the Age of the Apostles.

The very essence of ecclesiastical jurisdiction with its sanction of excommunication-can be traced to Christ's own words as recorded in St. Matthew's Gospel :6

"Moreover if thy brother shall trespass against thee, go and tell him his fault between thee and him alone: if he hear thee, thou hast gained thy brother.

"But if he will not hear thee, then take with thee one or two more that in the mouth of two or three witnesses every word may be established.

"And if he shall neglect to hear them, tell it to the church: but if he neglect to hear the church, let him be as an heathen man and a publican.

"Verily I say unto you, Whatsoever ye shall bind on earth shall be bound in heaven: and whatsoever ye shall loose on earth shall be loosed in heaven."

Criminal spiritual jurisdiction was exercised by the Apostles: St. Paul directed that the incestuous Corinthian should be put out of the church, ${ }^{7}$ and expelled Hymenaeus and Alexander for blasphemy.8

Ecclesiastical jurisdiction as exercised during the Early Roman Empire following the Apostolic Age until the conversion of the Empire to Christianity. After the Apostolic Age, criminal spir-

5 Sherman, Roman law in the modern world, vol. i, $\S \S 379,229$.

6 Matthew, xviii, 15-18.

71 Corinthians, ch. 5 .

81 Timothy, 20. 
itual jurisdiction was exercised by each bishop over his churches. But St. Ignatius ${ }^{9}$ held that this authority should be exercised with the advice of his presbyters. With the coalescing of episcopal dioceses into provinces, and provinces into still larger districts (in imitation of the administrative organization of the Roman Empire) provincial synods of the bishops and other still larger synods acquired a criminal spiritual jurisdiction, - at first original jurisdiction principally over bishops.

In this period began the exercise of appellate jurisdiction as to the clergy and laymen. Although a bishop had no formal right of appeal from the jurisdiction of a synod over him, yet sometimes other bishops would refuse to recognize a synodical sentence of deposition as unjust and would continue to communicate with the bishop as if not sentenced.

In the 3d century St. Cyprian expressed the theory of the church of his age in declaring that the Apostolic power of delegated sovereignty from the Lord, whether judicial or legislative, was held in joint-tenancy by all the Catholic bishops as a body in succession to the Apostles. But gradually a certain preeminence was conceded to bishops occupying sees traditionally - founded by Apostles, or sees of great secular importance.

Even before the Edict of Milan made Christianity a lawful religion, the Roman secular courts sometimes had recognized certain indirect temporal consequences of spiritual sentences of deposition from the ministerial office. The famous example is the case of Paul of Samosata, bishop of Antioch, who was deposed and excommunicated in $269 \mathrm{~A}$. D. by a great synod of the district of Antioch. But Paul refused to give up possession of the episcopal residence, notwithstanding his sentence. The Civil courts of the Empire were invoked to enable the local church to recover the see residence. The court wrote to the Emperor Aurelian for a rescript to decide the cause. The Emperor referred the case to the bishop of Rome who decided in favor of the Church of Antioch.

Antiquity and meaning of the terms "Canon" and "Canon law." In the Roman law the term canon signifies a rent or stipend payable at some regular time, generally annual: e. g., canon frumentarius, - the wheat tribute from the grain provinces of Rome; the lessees of public lands had to pay a perpetual rent

${ }^{9}$ Ch. 100. 
or "canon"at some periodical time. All this is quite different from the ecclesiastical import of the word "canon."

In its ecclesiastical sense the term "canon" has a comprehensive and a narrow meaning. (1) The general meaning of the word is "every ecclesiastical statute or regulation." 10 With the formation of Christian congregations, or churches, ' $E_{\kappa \kappa} \lambda$ joía certain rules were agreed upon for their government. The language of the early Christian church was Greek: these rules were known by the Greek term $K a ́ \mathrm{~V} \omega \mathrm{V} \epsilon s$, or canons. Their Latin synonyms were canones, forma, disciplina. Holy Scripture is called "Canon" because it is the supreme rule to govern the Church and the faith and life of Christians. The first eight general or ecumenical councils of the Church call their decisions as to discipline "canons," but their decisions as to faith, "dogmas." 11 The comprehensive terms canonica sanctio (canonical sanction), lex canonica (a canon law or statute), and canonum jura (laws of the canons) were not introduced until the 9th century of the Christian era, nor was the term jus canonicum (Canon law) employed until ecclesiastical law began in the 12th century to be treated as a science. The 6th century monk Dionysius the Little (Exiguus) is said to have been the first to give the name jus (law) to ecclesiastical regulations; at any rate, the expression jus canonicum (Canon law) became generally used from the 12th century onward.

(2) The word "canon" in medieval ecclesiastical law came to have a narrow meaning: the statutes of a bishop, or of a chapter, or the rules of a religious order (such as the Franciscans) are called "canons." And this narrow meaning still lingers in Church of England law. But in the Roman Catholic ecclesiastical law of today the term "canons" is now very largely reserved for (1) laws inserted in the great medieval codification known as the Corpus Juris Canonici, and (2) for the apostolic declarations of whatever date concerning a point of faith or discipline, e. g., the Apostolic Canons, the canons of General Councils. All other ecclesiastical law is called by Roman Cath-

10 "Canonum quidem allii sunt statuta counciliorum, allii decreta pontificum aut dicta sanctorum"; Can. 2, Dist. 3 (Decretum, Corp. Juris Canonici).

11 The last Catholic church council of a general nature (Trent, in $1545)$, on the contrary, designates under the name of "Canons" its definitions and anathemas, and calls its ordinances on the reformation of discipline "decreta": such is the change of usage since Imperial Roman times. 
olic canonists by special terms, such as bullae (bulls), motus proprii, decrees, rules of chancelleries.

Influence of the Roman Civil law on early Canon or Ecclesiastical lawe. There is no doubt "that Roman jurisprudence provided early Christian teachers" from the times of the Apostles themselves in the 1st century "with language and modes of thought by means of which they (these Christian teachers) might give expression to the truths they desired to propagate." ${ }^{12}$ Indeed a "knowledge of Roman law is of practical use for purposes of New Testament exegesis. If King James' bishops or the later Revisers had possessed it, fewer texts in the English Bible would have been confused and meaningless." 13 An examination, even hurriedly, of the writings of St. Paul, Tertullian, and other early Christian teachers markedly substantiates the fact that it was Roman jurisprudence which frequently gave them modes of thought and colored their religious and ethical doctrines.

1. St. Paul. The only Apostle with a legal training was St. Paul. ' $\mathrm{He}$ was a Roman citizen, when citizenship counted enormously in the Roman world, while his fellow Apostles were only Roman subjects. ${ }^{14}$ St. Paul's personifications in his writings are always legal. For instance, he incorporated into the language of theology and devotion the legal metaphor of the Roman adoption: he is the only writer to use this metaphor, so intelligible to the non-Hebrew nations of his time. Again, St. Paul uses the legal metaphor of the Roman heirship (hereditas): perhaps the most daring of all the theological conceptions of Paul is that which defines Christian believers as "heirs of God and joint heirs with Christ." Lastly, there is a striking passage in his Epistle to the Galatians which relates to the Roman law of guardianship.

2. Roman law in the ceremonies and ritual of the Early Christian Church. The following instances refer to nuodern church ceremonies which can be traced back in their essential features to the Early Christian church. Without going into details of illustration, the baptismal service of most churches bears unmistakable traces of the influence of Roman juris-

12 Ball, St. Paul and Roman Law, p. vii.

13 Id.

${ }^{14}$ This Republican and Early Imperial distinction is explained in Sherman, Roman law in the modern world, $\$ \S 43,44,56,58$. 
prudence. Parts of the office of baptism have been framed upon the pattern of the Roman contract of stipulatio (question and answer) and also on the claim with the rod, in the ceremony of adoption. ${ }^{15}$ In the marriage service is encountered the Roman stipulatio or contract formed by question and answer. ${ }^{16}$ The Anglican and Protestant Episcopal ordination of priests and the consecration of bishops also reiterate the influence of the Roman stipulatio in the form of these ceremonies. ${ }^{17}$

3. Tertullian and Lactantius. Tertullian, one of the fathers of the Church, and who was converted to Christianity in 185 A. D. (five years after the death of the Emperor Marcus Aurelius), was a lawyer, and practiced at Rome. $\mathrm{He}$ was a contemporary of the great Roman jurists Papinian, Gaius, Ulpian, and Paulus. Perhaps Tertullian is that "Tertullian" whose fame as a jurist is preserved in Justinian's Digest. ${ }^{18}$ The title of one of the ecclesiastical Tertullian's books shows his lawyer-like mind, $D e$ praescriptione haereticum (notice the technical Roman law term "praescriptio" borrowed by him to substantiate his argument that beliefs which had been in the field since the days of the Apostles were on this account alone entitled to protection "by prescription" against the new-fangled theories of heretics). It was Tertullian who first employed the word "Trinity" to express the Godhead ${ }^{19}$ and, by importing "into the sphere of theology the Roman legal conception of a person as an individual acting in some particular capacity or condition, and also the corollary that a single person might play many parts (personae)," declared that God, although a unit, might be considered under the several personalities of Father, Son and Holy Spirit. Lactantius, who died in the very year of the famous Nicene Council, reveals his original profession as a lawyer by his principal work, The Divine Institutes (notice the title "Institutes", - one hitherto immemorially reserved for beginners' legal text-books of Roman law students): in this work Lactantius "tries' to explain the mystic relationship between God

15 See Ball, St. Paul and Roman law, pp. 12, 39.

16 Id., p. 49.

17 Id.

18 See Sherman, Roman law in the modern world, vol. i, \$§ 106, 118.

19 Ball, p. 82.

20 Sherman, Id., vol. i, \$ 118. 
and Christ on the basis of the Roman law relationship of the paterfamilias and his son in power." 21

Finally, it is often overlooked that from the latter part of the $3 d$ century onward the leading bishops possessed a previous training in the Roman Civil law. St. Cyprian, St. Ambrose, St. Augustine, St. Paulinus of Nola, and St. John Crysostom had practiced law either as teachers or advocates at the Bar. Furthermore St. Ambrose and St. Paulinus had held high administrative and judicial offices of State.

Conversion of Constantine to Christianity in the year 310 $A$. $D$. The truth of the celebrated story of the conversion of - Constantine by reason of the flaming cross in the heavens, as related by Eusebius, has been greatly doubted by critical historians. That Constantine however was a friend to the Christian church cannot be denied. Naturally he may have been influenced in this direction when a youth, for his mother Helena was a Christian. The character of Constantine does not reveal any evidence of a personal assimilation of the truths of Christianity. He did not become openly a Christian until very late in life, and throughout his life he seems to have adopted a policy of double dealing with the new religion: that is, while favoring Christianity, he also tried to obtain all the benefit possible from the relics of paganism. For instance, "he not only called himself the Bishop of Bishops, and assumed a sort of headship over the Christian clergy, but he also retained to the last the title of Pontifex Maximus, which marked his supremacy over the pagan hierarchy." 22

The Edict of Milan, - the decree of Roman religious toleration enacted by Constantine the Great in $313 \mathrm{~A}$. D. The effect of this statute ${ }^{23}$ was to make Christianity a lawful Roman religion: previously the Church had been an illegal society. From the date of the Edict of Milan the Roman Empire, although tolerating other religions, recognized Christianity, the organization of the Christian Church, the decrees of its general and provincial Councils, the jurisdiction of Ecclesiastical Courts, and permitted the Church to enjoy the benefit of property received by gift or bequest. ${ }^{24}$

Christianity becomes the only lawful Roman religion. The

21 Id., vol. i, \& 119.

22 Morey, Roman law, p. 144.

23 Its text is given in Sherman, Roman law in the modern world, vol. $i$, $\$ 145$, footnote.

2411 Laws of Eng., p. 357. 
Emperor Julian, who ascended the throne about 25 years after the death of Constantine the Great in 337, tried to subvert Constantine's work and return to the religion of paganism. For this he has been branded in history as "Julian the Apostate," which is unjust; for Julian-an emperor of marked ability-indulged in no Neronian or Diocletian persecution of the Christians, and really adopted the policy of Constantine, only reversed, as to the two religions. Under Jovian, Julian's successor, the policy of Constantine was again adopted, and by the time we reach Theodosius the Great in 379 (16 years after the death of Julian) the pagan religion is completely proscribed and its temples demolished. Theodosius was an ardent believer, and very intolerant of heretics and pagans. Religious toleration was not practiced any more or so much by Christians of this period as under Emperors confessedly pagan.

Supremacy of the Roman State over the Church in the Later Roman Empire. Constantine the Great himself adopted and practised the principle that the Church is subservient to the State,-witness his assembling of the clergy in the famous Council of Nicaea, 325 A. D., to determine and fix the orthodox belief.

His Imperial successors, including Justinian, always maintained the pricinple of the subjection of the Church to the State. As a legal corporation recognized by Roman law, the Church was regulated by the Emperor. The Imperial legislation of Justinian asserted a majestic superiority over the Church and its Canon law. He begins his Code by formulating an Imperial creed on the Trinity, and by hurling an Imperial anathema against heretics like Nestorius and Apollinarius: he lays down laws for the clergy and regulates their authority; he makes the bishops Imperial officers for certain temporal affairs, e. g., before the bishops, guardians of lunatics swore on the Gospels to administer their trust with fidelity. ${ }^{25}$

Immunities and privileges of the clergy. The priest, as a citizen, was amenable to the law of the State; as a priest, however, he was amenable to the canons of the Church. Lay citizens or magistrates, as Christians, were subject also to the canons of the Church.

(1) Perhaps the earliest immunity of the clergy was to relieve them from the public burdens to which all other

25 See Sherman, Roman law in the modern world, vol. ii, $\$ 903$. 
citizens were subject. These public burdens (munera) included taxes, and personal services to the local community or to the State. (2) Again, very early the Emperors endowed the churches and gave them the legal right to receive legacies. ${ }^{26}$ (3) The clergy obtained certain judicial authority. This will be considered separately a little later. (4) Lastly, the heathen right of asylum of temples, their sanctity as places of refuge, was conferred upon Christian churches. Wills of Christians, following the pagan practice as to temples, were often deposited for safe-keeping in churches. The pagan right of intercession for condemned persons and criminals was also conferred on the Christian clergy.

Growth of ecclesiastical jurisdiction in the Later Roman Empire from Constantine onzward. (1) Criminal jurisdiction. The recognition of Christianity by the Roman State, was soon accompanied by a great development in criminal ecclesiastical jurisdiction. The secular power began to support the decrees of the Church. Episcopal and synodal sentences were made effective throughout the Empire.

The Council of Nicaea decreed that any person, whether minister or layman, cut off from communion in one province, should not be admitted as communicant elsewhere. But such excommunicated person sentenced by a bishop was given a right to appeal. And the celebrated trial of St. Athanasius led to extensions of the right to appeal, as formulated by the First Nicene Council.

In the 5th century the great patriarchates were constituted, and these became authorities superior to metropolitan and provincial synods.

Theodosius the Great began the system of bestowing secular criminal authority on recclesiastical Courts. ${ }^{271}$ And by a statute of the Emperor Honorius in $412^{28}$ it was provided that no clergyman should be accused criminally except before the bishop, i. e., clerics were removed from the jurisdiction of the secular courts in criminal cases. The Emperor Justinian, while not depriving a bishop of his jurisdiction to try and punish ecclesiastical offenses, ${ }^{29}$ provided that if the offense was a secular crime the clergyman shall be accused

26 This power was granted by Constantine the Great.

${ }^{27}$ Cod. Theod., de Episcopis, 23 (376 A. D.); Cod. Theod., de Religione, 1 (399 A. D.); Cod. Theod., de Episcopis Ecc. et. Cler., 62 (Constantius, 355$)$.

${ }_{28}$ Cod. Theod., de Epis. Ecc. et Cler., 41. 
before his bishop who may depose him from his ministerial office; and then the competent Civil tribunal may take him and punish him according to the Civil laws. ${ }^{30}$

Books on Canon criminal law appeared as early as the 4th century, - the so-called "Libri poenitentiales". V e ry curiously the earliest manuals of penance in the Western church appeared in England and Ireland. Those of David in the 4th century, of Archbishop Theodore of Canterbury in the 6th century, and of the Venerable Bede and Egbert of York in the 8th century are works of special mention. These books of penance served as the foundation of the developing criminal branch of Canon law. Books on criminal procedure in ecclesiastical courts, such as the early "Ordines Romani" on ritual and the "Ordines judiciorum," were the forerunners of collections of formulae and precedents for the preparation of formal or official documents, such as the "Liber diurnus" of the 8th century, a Papal collection.

(2) Civil jurisdiction. The temporal jurisdiction of the church has also its roots in the New Testament. ${ }^{31}$ Originally it was based upon the free and voluntary consent of the parties to accept the arbitration of the bishop.

And Constantine the Great in his epistle to the Numidian bishops decreed that litigants could resort to their bishops, if they preferred the ecclesiastical adjudication to the judgment of the secular courts. ${ }^{32}$ In such a case the episcopal judgment was made irreversible and equivalent to that of the Emperor, and the civil authorities were to enforce it. St. Ambrose and St. Augustine spent much time in deciding civil suits.

The Emperor Honorius at the close of the 4 th century decreed that the faithful were privileged to resort to their bishops who should act as arbitrators by consent; but that no appeal to the civil courts was to be allowed, and the award of the bishop was to be enforced by the civil authorities. ${ }^{s s}$ The Emperors Valentinian and Justinian re-affirmed th is legislation.

29 Novel, 83.

${ }^{30}$ Novel, 123, Ch. 21.

3x See Matthew xviii, 15-17 (given supra); 1 Corinthians vi, 1-8, "Dare any of you having a matter against another, go to law before the unjust, and not before the saints?"

${ }^{32}$ Cod. Theod., Tit. de Episcopis.

${ }^{33}$ Cod. Justin., $1,4$. 
But when Charlemagne revived the Empire of the West in the beginning of the 9th century, he made it a matter of right for a litigant to transfer his cause from a secular court to an ecclesiastical tribunal. Evidently Charlemagne labored under the mistaken belief that he was following the authority of Constantine and Theodositus. ${ }^{34}$

Comparative jurisprudence greatly developed by law treatises composing Canon and Roman law comparisons. Although the beginnings of the study of comparative jurisprudence were inaugurated by the Roman jurist Gaius in the $3 \mathrm{~d}$ century of our era, ${ }^{35}$ yet to Canon law is largely due the necessary stimulus which led to the development of literature on comparative jurisprudence.

The earliest attempt at sustained comparison with the Roman Civil law is the Lex Dei or the Collatio Mosaicarum et Romanarum legum, the authorship of which is unknown and which was probably written about the year $390 \mathrm{~A} . \mathrm{D}^{36}$ Of the baldest description, the comparison is made by simple juxtaposition without any comment by the author. The Lex Dei consists of 16 Titles, all but one beginning with "Moyses dicit." The sixteenth begins with the words: "Scriptura divina sic dicit." The short statement of the Mosaic law at the head of each title is followed by a more or less lengthy collection of Roman juristic opinion,-Ulpian, Paulus, Papinian being usually cited.

The Roman and Canon laws are also compared in the postJustinian or Byzantine Nomocanones. Here the texts of the secular and the ecclesiastical law are compared with or without annotations. These are also post-Justinian sources of Canon law. A good example is the Nomocanon of Photius, published about 880 A. D.; in this the compiler contrasts the old secular Roman law of marriage with the changes introduced by the legislation of the Later Empire. Occasionally Photius states also the differences between the secular and the ecclesiastical law.

Charles P. Sherman, D.C. L.

Formerly Professor of Roman Law,

Yale University Law School.

348 Encycl. Britt. (11th ed.) p. 854.

35 Sherman, Roman law in the modern world, vol. i, § 86 .

${ }^{36}$ Id., \& 129. 